\title{
Insight into plant cell wall degradation and pathogenesis of Ganoderma boninense via comparative genome analysis
}

\author{
Ahmad Bazli Ramzi ${ }^{\text {Corresp., } 1}{ }^{\text {, Muhammad Lutfi Che Me }}{ }^{1}$, Ummul Syafiqah Ruslan ${ }^{1}$, Syarul Nataqain Baharum ${ }^{1}$, Nor \\ Azlan Nor Muhammad ${ }^{1}$ \\ 1 Institute of Systems Biology, Universiti Kebangsaan Malaysia, Bangi, Selangor, Malaysia \\ Corresponding Author: Ahmad Bazli Ramzi \\ Email address: bazliramzi@ukm.edu.my
}

\section{Background}

G. boninense is a hemibiotrophic fungus that infects oil palms (Elaeis guineensis Jacq.) causing basal stem rot (BSR) disease and consequent massive economic losses to the oil palm industry. The pathogenicity of this white-rot fungus has been associated with cell wall degrading enzymes (CWDEs) released during saprophytic and necrotrophic stage of infection of the oil palm host. However, there is a lack of information available on the essentiality of CWDEs in wood-decaying process and pathogenesis of this oil palm pathogen especially at molecular and genome levels.

\section{Methods}

In this study, comparative genome analysis was carried out using G. boninense NJ3 genome to identify and characterize carbohydrate-active enzyme (CAZymes) including CWDE in the fungal genome.

Augustus pipeline was employed for gene identification in $G$. boninense NJ3 and the produced protein sequences were analyzed via dbCAN pipeline and PhiBase 4.5 database annotation for CAZymes and plant-host interaction (PHI) gene analysis, respectively. Comparison of CAZymes from G. boninense NJ3 was made against G. lucidum, a well-studied model Ganoderma sp. and five selected pathogenic fungi for CAZymes characterization. Functional annotation of PHI genes was carried out using Web Gene Ontology Annotation Plot (WEGO) and was used for selecting candidate PHI genes related to cell wall degradation of $G$. boninense NJ3.

\section{Results}

G. boninense was enriched with CAZymes and CWDEs in a similar fashion to G. lucidum that corroborate with the lignocellulolytic abilities of both closely-related fungal strains. The role of polysaccharide and cell wall degrading enzymes in the hemibiotrophic mode of infection of $G$. boninense was investigated by analyzing the fungal CAZymes with necrotrophic Armillaria solidipes, A. mellea, biotrophic Ustilago maydis, Melampsora larici-populina and hemibiotrophic Moniliophthora perniciosa. Profiles of the selected pathogenic fungi demonstrated that necrotizing pathogens including $G$. boninense NJ3 exhibited an extensive set of CAZymes as compared to the more CAZymes-limited biotrophic pathogens. Following $\mathrm{PHI}$ analysis, several candidate genes including polygalacturonase, endo $\beta$-1,3-xylanase, $\beta$-glucanase and laccase were identified as potential CWDEs that contribute to the plant host interaction and pathogenesis.

\section{Discussion}


mechanisms underlying the production of CAZymes in G. boninense NJ3. Identification and profiling of the fungal polysaccharide- and lignocellulosic-degrading enzymes would further facilitate in elucidating the infection mechanisms through the production of CWDEs by G. boninense. Identification of CAZymes and CWDE-related PHI genes in $G$. boninense would serve as the basis for functional studies of genes associated with the fungal virulence and pathogenicity using systems biology and genetic engineering approaches. 


\title{
1 Insight into plant cell wall degradation and
}

2 pathogenesis of Ganoderma boninense via

3 comparative genome analysis

4

\author{
Ahmad Bazli Ramzi ${ }^{*}$, Muhammad Lutfi Che $\mathrm{Me}^{1}$, Ummul Syafiqah Ruslan ${ }^{1}$, Syarul Nataqain \\ Baharum $^{1}$, Nor Azlan Nor Muhammad ${ }^{1}$ \\ ${ }^{1}$ Institute of Systems Biology, Universiti Kebangsaan Malaysia, 43600 Bangi, Selangor, \\ Malaysia \\ Corresponding Author: \\ Ahmad Bazli Ramzi* \\ Institute of Systems Biology, Universiti Kebangsaan Malaysia, 43600 UKM Bangi, Malaysia \\ Email address: bazliramzi@ukm.edu.my
}

\section{ABSTRACT}

\section{Background}

G. boninense is a hemibiotrophic fungus that infects oil palms (Elaeis guineensis Jacq.) causing basal stem rot (BSR) disease and consequent massive economic losses to the oil palm industry. The pathogenicity of this white-rot fungus has been associated with cell wall degrading enzymes (CWDEs) released during saprophytic and necrotrophic stage of infection of the oil palm host. However, there is a lack of information available on the essentiality of CWDEs in wooddecaying process and pathogenesis of this oil palm pathogen especially at molecular and genome levels.

\section{Methods}

In this study, comparative genome analysis was carried out using G. boninense NJ3 genome to identify and characterize carbohydrate-active enzyme (CAZymes) including CWDE in the fungal genome. Augustus pipeline was employed for gene identification in G. boninense NJ3 and the produced protein sequences were analyzed via dbCAN pipeline and PhiBase 4.5 database annotation for CAZymes and plant-host interaction (PHI) gene analysis, respectively. Comparison of CAZymes from G. boninense NJ3 was made against G. lucidum, a well-studied model Ganoderma sp. and five selected pathogenic fungi for CAZymes characterization. Functional annotation of PHI genes was carried out using Web Gene Ontology Annotation Plot (WEGO) and was used for selecting candidate PHI genes related to cell wall degradation of $G$. boninense NJ3.

\section{Results}

G. boninense was enriched with CAZymes and CWDEs in a similar fashion to G. lucidum that corroborate with the lignocellulolytic abilities of both closely-related fungal strains. The role of polysaccharide and cell wall degrading enzymes in the hemibiotrophic mode of infection of $G$. 
40 boninense was investigated by analyzing the fungal CAZymes with necrotrophic Armillaria

41 solidipes, A. mellea, biotrophic Ustilago maydis, Melampsora larici-populina and

42 hemibiotrophic Moniliophthora perniciosa. Profiles of the selected pathogenic fungi

43 demonstrated that necrotizing pathogens including $G$. boninense NJ3 exhibited an extensive set

44 of CAZymes as compared to the more CAZymes-limited biotrophic pathogens. Following PHI

45 analysis, several candidate genes including polygalacturonase, endo $\beta$-1,3-xylanase, $\beta$-glucanase

46 and laccase were identified as potential CWDEs that contribute to the plant host interaction and

47 pathogenesis.

48 Discussion

49 This study employed bioinformatics tools for providing a greater understanding of the biological

50

51

52

53

54

55

56

57

58

59

60

61

62

63

64

65

66

67

68

69

70

71

72

73

74

75

76

77

78 mechanisms underlying the production of CAZymes in G. boninense NJ3. Identification and profiling of the fungal polysaccharide- and lignocellulosic-degrading enzymes would further facilitate in elucidating the infection mechanisms through the production of CWDEs by $G$. boninense. Identification of CAZymes and CWDE-related PHI genes in G. boninense would serve as the basis for functional studies of genes associated with the fungal virulence and pathogenicity using systems biology and genetic engineering approaches.

\section{INTRODUCTION}

Cell wall degrading enzymes (CWDEs) are part of the carbohydrate-active enzymes (CAZymes) produced by plant pathogens for penetrating and degrading the plant cell walls, and these CAZymes have been directly linked to devastating crop diseases (Zhang, Bruton \& Biles, 2014; Somai-Jemmali et al., 2017; Gawade et al., 2017). Plant pathogenic fungi, namely among the fungal families of Ascomycota, Basidiomycota, Chytridiomycota, and Zygomycota, have been reported to contain the highest number of CAZymes (Zhao et al., 2013; Kubicek, Starr \& Glass, 2014). Differences in composition and structure of the woody components are commonly mirrored with the types of lignocellulolytic enzymes produced by invading pathogenic fungi (King et al., 2011). In fact, many plant pathogens particularly white rot fungi are well-endowed with high copies of CWDEs as compared to decay-feeding saprotrophs and have been demonstrated to be highly competent producers of lignocellulolytic enzymes for host-specific attack, and subsequent biomass degradation (King et al., 2011; O'Connell et al., 2012).

Interestingly, genome and transcriptome analyses indicate different profiles of CAZymes were produced by pathogenic fungi during different stages of pathogenesis transition from biotrophic to necrotrophic lifestyles (O'Connell et al., 2012; M'Barek et al., 2015). Enzymatic production of CWDE by pathogenic fungi has been found to be correlated with the degree of pathogenicity and cell wall disintegration of infected plant hosts (Kang \& Buchenauer, 2000; Wanjiru, Zhensheng \& Buchenauer, 2002; Lyu et al., 2015; Somai-Jemmali et al., 2017). Considering the importance of CWDE in the uptake of nutrients from plant host, these hydrolytic enzymes are considered as the key pathogenicity determinant among plant pathogens (Brito, 
79 Espino \& González, 2006; Kubicek, Starr \& Glass, 2014; Bravo Ruiz, Di Pietro \& Roncero, 80 2016).

81 Ganoderma boninense is a causative agent of basal stem rot (BSR) disease that beset the 82 oil palm industries with devastating economic losses due to the reduced lifespan and eventual 83 death of the infected oil palm (Chen et al., 2017). Due to the toxicity and environmental issues of 84 chemical pesticides, the Ganoderma disease is currently managed mainly through cultural 85 practices such as the removal of dead trees and infected stumps prior to or during replanting but 86 these strategies remain ineffective in preventing the spread of the G. boninense in affected 87 plantations (Hushiarian, Yusof \& Dutse, 2013; Sahebi et al., 2015). Recent research works in 88 overcoming the Ganoderma disease has been mainly aimed at understanding the oil palm 89 molecular defense response via transcriptional analysis, and profiling of proteins and metabolites 90 of the infected oil palm (Nusaibah et al., 2016; Sahebi et al., 2017; Ho et al., 2018). The spread

91

92

93

94 95 96 97 98 99 of $G$. boninense in oil palm plantation has been attributed to two main routes specifically spore dispersal and root contact with $G$. boninense infected palm tissues (trunk, bole, and roots) (Paterson, 2007; Chen et al., 2017). Importantly, root infection via cell wall degradation has been suggested as the main mode of Ganoderma infection based on the spread of infection from root to the base of mature palm trees (Rees et al., 2009).

Lignocellulolytic enzymes of $G$. boninense have been shown to be predominant in instigating oil palm infection and cell wall-degrading processes (Goh, Ganeson \& Supramaniam, 2014; Jumali \& Ismail, 2017; Surendran et al., 2018). Direct roles of CWDEs in the hemibiotrophic infection of oil palm roots were first demonstrated via macroscopic examination of enzymatically-degraded root outer cell layers and invaded root and stem tissues of $G$. boninense-infected tissues (Rees, 2006; Rees et al., 2009). In the initial stage of infection, the fungal mycelia behave as biotrophs that absorb the plant nutrient by penetrating the oil palm root surface and culminating in rapid growth spread in oil palm lower stem. During the necrotrophic stage, the fungus attacks the host cell walls by excreting host of enzymes including CWDEs that led subsequent cell death and multiplication of basidiocarps in decayed palm woods (Rees et al., 2009; Chong, Dayou \& Alexander, 2017).

Despite the important roles of CWDEs in the oil palm pathogenesis, information about genomic features and mechanisms underlying the pathogenicity of $G$. boninense in oil palm is severely lacking. The necessity for establishing a reliable genetic model for understanding Ganoderma-oil palm interactions is highlighted in recent reports of draft genome sequences of different strains of $G$. boninense which could facilitate the identification of CWDEs as pathogenicity factors essential for successful invasion of oil palm cells (Sulaiman et al., 2018; Utomo et al., 2018). A deeper understanding on the genetic composition of CWDEs as part of carbohydrate-acting enzymes of $G$. boninense and the biological mechanisms conferring the fungal ability to produce CWDEs are important in our efforts to elucidate the plant-pathogen interactions at the genome and molecular levels. Therefore, this research work was devised to obtain genomic insight of CWDEs in G. boninense through computational and comparative genome analysis. Genome sequence of $G$. boninense NJ3 that was isolated from Malaysian oil

PeerJ reviewing PDF | (2018:12:33674:3:0:NEW 14 Oct 2019) 
119 palm field was used for the comparative genome analysis (Mercière et al., 2015). In this study, 120 CAZymes specifically auxiliary protein (AA), glycosyltransferase (GT), carbohydrate binding 121 modules (CBMs), carbohydrate esterases (CE), glycoside hydrolases (GH) and polysaccharide 122 lyases (PL) in G. boninense NJ3 genome were annotated using CAZy annotation pipeline. Direct 123 comparison of CAZymes was made with close relative and model strain G. lucidum as the

124

125

126

127

128

129

130

131

132

133

134

135

136

137

138

139

140

141

142

143

144

145

146

147

148

149

150

151

152

153

154

155

156

157

158

reference Ganoderma strain. Further comparison was carried out with five selected pathogenic Basidiomycetes in the search for genetic patterns underlying G. boninense hemibiotrophic infection strategy. Identification of the responsible genes for $G$. boninense CAZymes including CWDEs will broaden genomic understanding on the molecular mechanisms of the fungal wooddecaying abilities and oil palm pathogenesis

\section{MATERIALS \& METHODS}

\section{Ganoderma boninense NJ3 genome}

The G. boninense NJ3 assembled genome was obtained from the NCBI assembly database (GenBank assembly accession: GCA_001855635.1). The assembly level is at contig level and was sequenced using Illumina HiSeq 454 in 2016. Comparative genome analysis was carried out by comparing CAZymes dataset of $G$. boninense NJ3 with previously-reported genome sequence of Ganoderma lucidum (Chen et al., 2012b), Melampsora larici-populina (Duplessis et al., 2011), Ustilago maydis (Kämper et al., 2006), Moniliophthora perniciosa FA553 (Mondego et al., 2008), Armillaria solidipes 28-4 (Sipos et al., 2017) and Armillaria mellea DSM 3731(Collins et al., 2013). Except for G. lucidum, archival CAZymes information of the other referenced fungal genomes was retrieved from Joint Genome Institute MycoCosm portal in May 2018 (Grigoriev et al., 2014) (https://gp-dge6.jgi.doe.gov/programs/fungi/index.jsf).

\section{Prediction of genes}

The contigs from the $G$. boninense NJ3 assembly was processed using Augustus gene prediction tool for the identification of genes (http://augustus.gobics.de/). Gene prediction was carried out using "augustus --species=phanerochaete_chrysosporium gboninense_NJ3.fna > gboninense_NJ3_augustus.gff” command where gboninense_NJ3.fna was the assembled contigs file. Phanerochaete chrysosporium was chosen as the gene prediction model as it was the closest species to G. boninense in Augustus based on the NCBI taxonomy browser (https://www.ncbi.nlm.nih.gov/Taxonomy/Browser/wwwtax.cgi). A GFF file containing the genes predicted and their annotations was produced by Augustus and the protein sequences were then extracted via the command "getAnnoFasta.pl gboninense_NJ3_augustus.gff”. The predicted genes dataset of the G. boninense NJ3 genome has been deposited at European Nuclear Archive (ENA) under the accession number PRJEB34805.

\section{dbCAN pipeline analysis}

The produced protein sequences from Augustus was searched against the dbCAN: An HMM (Hidden Markov Model) based database for carbohydrate-active enzyme annotation. dbCAN

PeerJ reviewing PDF | (2018:12:33674:3:0:NEW 14 Oct 2019) 
159

160

161

162

163

164

165

166

167

168

169

170

171

172

173

174

175

176

177

178

179

180

181

182

183

184

185

186

187

188

189

190

191

192

193

194

195

196

197

198

release 6.0 was downloaded in May 2018. The downloaded database was converted into a HMM formatted database using hmmpress (part of HMMER3 software package). hmmscan was run with the following parameters; --domtblout results.out.dm. hmmscan-parser.sh (from dbCAN) was used to process the results table with e-value 1E-3 as filter.

\section{Annotation by PhiBase 4.5 database}

PhiBase 4.5 was downloaded for local analysis from http://www.phi-base.org. The raw sequence file was converted into a blast database using makeblastdb (part of the ncbi-blast+ software package). A local blastp run was deployed to identify homologs of PhiBase 4.5 in $G$. boninense $\mathrm{NJ} 3$ predicted protein sequences. Blastp was run with the parameters -outfmt 6 -max_target_seqs 1 -max_hsps 1 -evalue 0.1 .

\section{Gene ontology and WEGO chart}

Gene ontology of PhiBase 4.5 homologs in G. boninense NJ3 was obtained using Blast2GO 5.2.5 pipeline. Using local blastp function in Blast2GO, the sequences of the homologs were annotated against the NCBI NR (non-redundant) protein database. The NR database was downloaded in April 2019. E-value chosen was 0.1 and number of blast hits was set to 10. Other parameters remained at default values. The gene ontologies were then mapped onto the sequences by mapping the latest Blast2GO database with the blasted sequences. Next, InterProScan 5.33-72 was ran locally to obtain protein domain annotations. The XML file produced was then loaded in Blast2GO. Lastly, the annotation tool in Blast2GO merged and verified the gene ontologies obtained between both gene ontology annotation methods. Blast2GO annotation parameters were left at default values. Functional classification of PHI genes was carried out using Web Gene Ontology Annotation Plot (WEGO) software (Ye et al., 2006). To generate the WEGO chart, we exported the results from Blast2GO annotation in WEGO native format. The WEGO chart was then generated by uploading to http://wego.genomics.org.cn/. Datasets of $G$. boninense NJ3 Augustus gene annotation, GO annotation and protein ID from PhiBase 4.5 analysis are provided in supplementary files.

\section{RESULTS \& DISCUSSION}

\section{Characterization of carbohydrate-active enzymes (CAZymes) in G. boninense}

In this study, the draft genome of $G$. boninense $\mathrm{NJ} 3$ was used for identifying and characterizing the carbohydrate-active enzymes in fungal genome. To identify CAZymes in $G$. boninense NJ3, the assembled dataset was further processed using Augustus pipeline to produce predicted genes peptide sequence for CAZymes analysis via the dbCAN pipeline. Comparative analysis for CAZymes characterization in G. boninense was carried out using G. lucidum genome sequence as the reference Ganoderma spp. strain owing to the high-quality genome sequence and well-established genomics studies of this closely-related Ganoderma strain. We hypothesized that $G$. boninense is enriched with a high number of CAZymes similar to $G$. lucidum that provide wood-degrading capabilities and contribute to the disparate nutritional 
199

200

201

202

203

204

205

206

207

208

209

210

211

212

213

214

215

216

217

218

219

220

221

222

223

224

225

226

227

228

229

230

231

232

233

234

235

236

237

238

strategy of hemibiotrophic G. boninense and saprophytic G. lucidum, respectively.

Following analysis, a total of 755 CAZymes was identified in G. boninense NJ3 as compared to 489 CAZymes found in G. lucidum (Fig. 1). Overall, about 465 copies of cell wall degrading enzymes (CWDEs) comprising of glycoside hydrolase $(\mathrm{GH})$, carbohydrate esterase (CE) and polysaccharide lyase (PL) were found in the $G$. boninense NJ3 genome. From the total CWDEs, 348, 102 and 15 genes were found for GH, CE and PL, respectively (Table S1). The amount of CWDEs found in $G$. boninense is comparatively higher when compared with $G$. lucidum (273 GHs, 30 CEs, 10 PLs). A richer and highly similar set of CWDEs was observed in $G$. boninense NJ3 that enables degradation of woody structures such as hemicellulose and pectin for nutrient uptake and growth in similar means to G. lucidum which harbored one of the richest sets of polysaccharide-degrading enzymes in the sequenced genome of Basidiomycota fungi (Chen et al., 2012b). Interestingly, G. boninense NJ3 possesses a higher number of CEs of about 102 copies as compared to G. lucidum with 30 copies of CEs that are important for plant cell wall modification. In addition to polysaccharide-deacetylating CE enzymes, G. boninense NJ3 also harbors a diverse array of GHs that are crucial in the hydrolysis of cellulose and hemicellulose components of the plant biomass. Common GH in white rot fungi such as GH6 and GH7, and universal CWDEs of cellulolytic GH1, GH3 and GH5 for degradation of cellulose, hemicellulose and pectin were observed in both Ganoderma spp. Importantly, G. boninense possesses several GHs that were not found in G. lucidum specifically polysaccharides-acting GH109 ( $\alpha$-N-acetylgalactosaminidase), GH145 (L-Rh $\alpha-\alpha-1,4-G l c A \alpha-L-r h a m n o h y d r o l a s e)$, GH135 ( $\alpha$-1,3-galactosaminogalactan hydrolase) and GH131 (broad specific $\beta$-glucanase) that degrade both cellulose and hemicellulose. In terms of polysaccharide-active enzymes, both Ganoderma spp. contained multiple copies of pectic-acting PL8 and PL14 while PL4 (rhamnogalacturonan endolyase), PL12 (heparin-sulfate lyase) and PL15 (alginate lyase) were only found in G. boninense.

Apart from CWDEs, both fungal genomes harbored other CAZymes including carbohydrate binding module (CBM), auxiliary activity (AA) and glycosyltransferase (GT) that are essential for lignin depolymerization and carbohydrate utilization from the host plant. During wood decaying process, access to the structural woody components was aided by CBMs that formed a two-domain structure together with catalytic domains (CDs) of cellulases by increasing the enzyme concentration on the substrate surfaces. Overall, a total of 290 copies of CAZymes was identified in G. boninense NJ3 as compared to 176 copies in G. lucidum. Of these, 67 CBMs, 145 AAs and 78 GTs were identified from G. boninense. Both Ganoderma spp. strains have a similar set of CBMs except for CBM19 (chitin-binding function) and CBM32 (pecticbinding) were unique for $G$. boninense while CBM12 (chitin-binding) was only found in $G$. lucidum. Although white rot fungi have been associated with lack of CBMs, G. lucidum and $G$. boninense contained 10 and 12 out of 16 total families of CBMs, respectively. It is notable that G. boninense possessed high copies of CBM1, an important fungal CBM that uses cellulose and chitin as substrates for polysaccharide-degrading activities (Mello \& Polikarpov, 2014; Várnai et al., 2014). Both fungi shared similar GTs except for GT65 and GT41 that were found only in $G$.

Peer) reviewing PDF | (2018:12:33674:3:0:NEW 14 Oct 2019) 
239

240

241

242

243

244

245

246

247

248

249

250

251

252

253

254

255

256

257

258

259

260

261

262

263

264

265

266

267

268

269

270

271

272

273

274

275

276

277

278

boninense while GT31 was present only in G. lucidum. The ability of Ganoderma spp. to utilize

nutrient from plant tissues relied heavily on the synergistic actions of cellulolytic and ligninolytic enzymes that include redox AA enzymes (Zhou et al., 2018). Laccase (AA1_A1), ferroxidase (AA1_A2), class II peroxidase (AA2), GMC oxidoreductase (AA3), radical-copper oxidase (AA5), 1,4-benzoquinone reductase (AA6) and iron reductase (AA8) were among AA enzymes identified in both sets of fungal genomes. From this comparative analysis, G. boninense was found to be endowed with significantly higher copies of the redox enzymes especially ligninacting laccase (AA1) and peroxidase (AA2) and oxidoreductase (AA3) enzymes as compared to G. lucidum.

Lignocellulolytic enzymes production has been well-documented in white rot Ganoderma spp. for wood decomposition and subsequent feeding and propagation on the woody substrates (Silva, Melo \& Oliveira, 2005; Paterson, 2007; Zhou et al., 2013). Apart from wooddegrading enzyme producing capabilities and plant pathogenicity, Ganoderma species are generating much research interest for therapeutic applications through the production of bioactive polysaccharides and terpenoids such as ganoderic acid (Boh, 2013; Wu et al., 2013). Owing to its therapeutic and biotechnological potentials, G. lucidum has been developed as model medicinal mushroom through extensive biochemistry, genomics, and genetic engineering research, and this saprophytic mushroom is in fact endowed with an extensive set of CAZymes encoded in its genome (Xu, Xu \& Zhong, 2012; Chen et al., 2012b; Liu et al., 2012; Yu et al., 2012). In this study, the genome sequence of $G$. boninense NJ3, a pathogenic fungal isolate from oil palm plantation in Malaysia (Mercière et al., 2015), was employed for identifying genes involved in the production of cell wall degrading and carbohydrate active enzymes. By comparing CAZymes of $G$. boninense NJ3 with model $G$. lucidum, profiles of these close-related Ganoderma spp. can be acquired especially in terms of the cell wall degrading abilities of the lesser-studied G. boninense. Based on the results obtained, G. boninense NJ3 was found to be enriched with an extensive repertoire of CAZymes in similar fashions but with significantly higher numbers of lignocellulosic-degrading enzymes as compared to the non-pathogenic $G$. lucidum, hence, underlining the essentiality of CAZymes in cell wall degradation for the fungal growth and nutrient uptake. Differences in CAZymes characteristics especially CWDEs and polysaccharide-active AAs can be linked and predetermined by the nutritional strategy of either Ganoderma spp. hence providing genomic insight and characterization of plant cell wall degradation mechanism of these industrially-important fungi.

\section{Profiling of CAZymes in selected phytopathogenic fungi}

Following characterization of CAZymes in G. boninense, the innate ability of this white rot fungus to cause oil palm BSR disease was further investigated by comparative analysis with a few selected disease-causing Basidiomycetes. For this purpose, five phytopathogenic basidiomycetous fungi exhibiting the biotrophic, hemibiotrophic and necrotrophic mode of plant infections were employed for comparison with $G$. boninense. The fungi of interest were Ustilago maydis (model biotrophic pathogen), Melampsora larici-populina (biotrophic poplar pathogen), 
279

280

281

282

283

284

285

286

287

288

289

290

291

292

293

294

295

296

297

298

299

300

301

302

303

304

305

306

307

308

309

310

311

312

313

314

315

316

317

318

and Moniliophthora perniciosa (hemibiotrophic cocao pathogen). The remaining two fungi were Armillaria solidipes and $A$. mellea representing facultative necrotrophic fungi attributed to root rot in many conifers and ornamentals, respectively (Kämper et al., 2006; Duplessis et al., 2009; Meinhardt et al., 2014; Koch et al., 2017). Biotrophs primarily depend on and derive nutrients without killing the hosts while necrotrophs kill the plant and feed nutrients off the dead cells (Mendgen \& Hahn, 2002). On the other hand, hemibiotrophs adopt early asymptomatic biotrophic phase and then switched to the host-killing necrotrophic stage with distinct disease symptoms, and decayed tissues (Horbach et al., 2011). Although each fungus may differ in targeting host and infection mechanisms, these plant pathogens have been found to rely on an array of hydrolytic enzymes for complete degradation of plant biomass for colonization and nutrient uptake with or without killing the hosts. In this study, we hypothesized that pathogenic fungi with necrotizing abilities (necrotroph and hemibiotroph) would harbor distinct CAZymes profile as compared to non-necrotizing fungi (biotroph) which may be attributed to specific host preference and interaction.

The profile of CWDE in all six pathogenic fungi was illustrated in Figure 2. $G$. boninense NJ3 contained glycosyl hydrolase (GH) GH2 and GH10 for specialized hemicellulose degradation in addition to dual cellulose and hemicellulose-degrading activities of GH1, GH3, GH5, GH12, GH51, and GH131. The ability of this oil palm pathogen to hydrolyse the pectin component is further provided by GH28, GH105 and necrotroph-specific GH53 and GH78. Biotrophic U. maydis and M. laricis-populina lack GH1, GH6, GH78 and GH95 which were prevalent in the necrotizing fungi ( $G$. boninense NJ3, M. perniciosa, A. solidipes and $A$. mellea) (Fig. 2a). Additionally, U. maydis lacked GH7 that is common among pathogenic white rot fungi. On the other hand, biotrophic U. maydis and M. laricis-populina possess GH26 which was not observed in other 4 necrotizing pathogens investigated in this study. The lack of GH1, GH6 and GH78 were well-documented in biotrophs which generally harbor less plant cell wall degrading enzymes than necrotrophs and hemibiotrophs (Zhao et al., 2013; Li et al., 2017). Obligate necrotrophs ( $A$. solidipes and $A$. mellea) and hemibiotrophs ( $G$. boninense NJ3 and $M$. laricis-populina) were evidently supplemented with $\mathrm{GH} 3$ and $\mathrm{GH} 28$ for cellulose, hemicellulose and pectin degradation. From the analysis, G. boninense NJ3 exhibited the highest copies of GH18 (Chitinase/endo- $\beta$-N-acetylglucosaminidase), GH43 (Hemicellulase), GH79 (Glucuronidase), GH10 (Xylanase) and harbored unique GH4 (glycosidase), GH89 ( $\alpha-\mathrm{N}-$ acetylglucosaminidase) and GH109 ( $\alpha$-N-acetylgalactosaminidase) for polysaccharide depolymerization in comparison to other plant pathogens examined in this study. Taken together, these findings highlighted the essentiality of several GHs specifically GH3 and GH5 for cell wall degradation by the phytopathogens that corroborated with previous reports on the plant host infection interplays by the phytopathogenic fungi (Zhao et al., 2013; Blackman, Cullerne \& Hardham, 2014; Chang et al., 2016).

In addition to cellulose and hemicellulose, some plants are enriched with pectins comprising of homogalacturonan, xylogalacturonan or rhamnogalacturonan as external barriers against pathogen infections. In G. boninense NJ3, the cell wall-degrading GHs could work in 
319 tandem with pectic-acting enzymes of polysaccharide lyase 8 (PL8), PL12, PL14 and PL15. 320 Common PL found in pathogens, PL1 and PL3 were not observed in G. boninense NJ3 which is

321

322

323

324

325

326

327

328

329

330

331

332

333

334

335

336

337

338

339

340

341

342

343

344

345

346

347

348

349

350

351

352

353

354

355

356

357

358 interesting considering the abundance of these PLs in necrosis-causing M. perniciosa, $A$. solidipes and $A$. mellea (Fig. 2b). Pectin degradation by pectinolytic enzymes particularly PL4 is common among necrotizing fungi examined in this study except $G$. boninense NJ3 and this enzyme had been shown to be highly expressed during crops infection by necrotrophic Rhizoctonia solani (Zheng et al., 2013; Chang et al., 2016). Although important for cell wall degradation by fungi, the smaller amount of pectinases in $G$. boninense NJ3 may indicate substrate or host preference specifically monocotyledon-type as compared to dicotyledonpreferred pathogens that have been associated with increased secretion of pectinases (Zhao et al., 2013; Loyd et al., 2018). Hemibiotrophic and necrotrophic fungi are well-equipped with the extended set of CWDEs which enable tailored and extensive production of the cell wall degrading enzymes during infection.

In this study, it was found that all 6 pathogenic fungi possess at least one copy of carbohydrate esterase 4 (CE4) as one of the polysaccharide-modifying enzymes in the genomes (Fig. 2c). The genome of $G$. boninense NJ3 was well-represented with CE16 in addition to CE1 and CE12 that were also found in necrosis-causing M. perniciosa, A. solidipes and A. mellea while CE2, CE14 and high copies of CE10 were found only in the pathogenic Ganoderma spp. CEs have been associated in the first line of attack during fungal invasion via the removal of acetylated moieties of saccharides that formed parts of plant protection system against hydrolytic enzymes (Ospina-Giraldo, McWalters \& Seyer, 2010; Sista Kameshwar \& Qin, 2018). The CE10 enzyme is involved in the degradation of lignin and cellulosic components of the plant cell wall and was found to be abundant in several pathogenic fungi including Macrophomina phaseolina, Bipolaris cookei and Corynespora cassiicola (Islam et al., 2012; Zaccaron \& Bluhm, 2017; Looi et al., 2017). In sum, notable differences in CWDE profiles of hemibiotrophic and necrotrophic fungi can be associated with the less aggressive nature of biotrophic U. maydis and M. laricispopulina that adapted the hydrolytic enzyme production specifically for limiting host cell wall damages hence supporting their host nutrient-dependent growth (Kämper et al., 2006; Duplessis et al., 2009; Olson et al., 2012).

Profiling of the remaining CAZymes in the six pathogenic fungi was carried out for comparing and establishing the association between mode of infection and type of genes present. Generally, glycoside transferase (GT) enzymes are mainly responsible for cell wall formation in contrast to the more abundant carbohydrate-hydrolysing GHs in the fungal genomes. As shown in Fig 3a, the six pathogenic fungi harbored highly similar set of GTs while GT71 is unique for biotrophs and GT65 was only found in G. boninense NJ3. Metabolism of starch components of the plant biomass is linked to the presence of starch-active carbohydrate binding modules (CBMs) including CBM1, CBM20, CBM48 and CBM50. Only CBM48 and CBM50 were found in all of the studied pathogens while CBM1 was missing in biotrophic U. maydis and M. laricispopulina which in turn, represented the most in G. boninense NJ3 genome (Fig. 3b). The occurrence of CBMs was often associated with facilitating the hydrolytic activities of amylolytic 
359

360

361

362

363

364

365

366

367

368

369

370

371

372

373

374

375

376

377

378

379

380

381

382

383

384

385

386

387

388

389

390

391

392

393

394

395

396

397

398

GHs such as GH13 and GH15 by increasing cell-substrate attachment and degradation (Chen et al., 2012a). In particular, CBM1-containing proteins have been found mainly in nectrotrophs and hemibiotrophs for promoting cellulose hydrolysis and were shown to elicit plant defense response which is detrimental for fungi with biotrophic lifestyle (Jones \& Ospina-Giraldo, 2011; Klosterman et al., 2011; Larroque et al., 2012).

For lignin decomposition, all six pathogenic fungi possessed auxiliary activities (AA) enzymes for AA1, AA3, AA5 and AA6 that encode for ligninolytic and redox enzymatic activities while phenolic-active AA4 (vanillyl-alcohol oxidase) was found only in G. boninense (Fig. 3c). Another important lignin-modifying enzyme, AA9 also classified as lytic polysaccharide monooxygenases (LPMO), is involved in lignocellulosic degradation by oxidizing cellulose in synergistic reactions with laccase and lignin-modifying peroxidase enzymes. On one hand, biotrophic fungi M. larici-populina and U. maydis harbored a smaller set of lignolytic AAs with about 36 (M. larici-populina) and 23 (U. maydis) as compared to the other studied pathogens. These biotrophic strains contained lesser copies of AA1 encoding for laccase and multicopper oxidase enzymes that involved in degradation of lignin barrier. All pathogens possessed AA9 except $U$. maydis while AA2 and AA8 were absent in both biotrophic fungi. High copies of AA9 observed in necrotrophs and hemibiotrophs studied may indicate the importance of these enzymes during the host attack and cell wall deformation. The identification of cellulose-cleaving oxidoreductases LPMOs as part of that AA9 family was previously associated with improved fungal cellulase and wood decaying activities with the presence of reducing agents (Dimarogona et al. 2013; Karnaouri et al. 2014). These auxiliary redox enzymes played an important role in completing hydrolysis of lignin by wood-decomposing saprotrophic fungi and have been associated with increased virulence of parasitic fungi (Hatakka, 1994; Levasseur et al., 2013; Janusz et al., 2017). The abundance of AAs may contribute to the enhanced ability of $G$. boninense NJ3 to invade and penetrate lignin and acetylated saccharides as it switches from biotrophic to necrotrophic parasitism that involves overlapped biological processes as found in forest pathogen and wood decayer Heterobasidion annosum sensu lato (Olson et al. 2012). The production of diverse ligninolytic enzymes by Ganoderma are therefore important for the fungal proliferation off plant tissues especially in the depolymerizing of the recalcitrant lignin barrier (Hu et al., 2017; Sarah Jumali \& Ismail, 2017; Zhou et al., 2018).

Expression patterns and production of carbohydrate-acting enzymes have been demonstrated to be correlated with the fungal mode of interactions with host plants.

Transcriptome analysis of $G$. boninense-treated oil palm transcripts showed very high expression of a host of distinct up-regulated genes encoding for CAZymes from lignin-degrading AAs (laccase and AA2 manganese peroxidase), carbohydrate-active CBM and CE (CBM13, CE10, CE9) to cell wall-hydrolyzing exo- $\beta$-1,3-glucanase, chitinase and polygalacturonase when compared to untreated and Trichoderma harzianum-treated control samples (Ho et al., 2016). Similar patterns of highly expressed CAZymes transcripts were observed in necrotrophic $A$. solidipes that exhibited high number of homologs of GH18, GH47, CE10, CE4 and polygalacturonase following plant-fungus inoculation (Ross-Davis et al., 2013). Higher

PeerJ reviewing PDF | (2018:12:33674:3:0:NEW 14 Oct 2019) 
399

400

401

402

403

404

405

406

407

408

409

410

411

412

413

414

415

416

417

418

419

420

421

422

423

424

425

426

427

428

429

430

431

432

433

434

435

436

437

438

expression of cell wall degrading enzymes (GH, PL, GT) were observed in necrotrophic Leptosphaeria biglobosa as compared to hemibiotrophic counterpart, L. maculans which accumulated higher CBM during early stage of plant infection (Lowe et al., 2014). Similar CAZymes interplays were suggested in the early infection of $G$. boninense that aimed at overcoming the oil palm host defense response mechanisms including hypersensitive response (HR) leading to the switch from biotrophic stage to the more aggressive necrotrophic attacks culminating in host cell death and successful invasion (Bahari et al., 2018). A closer look of the CAZymes in the selected pathogenic fungi would therefore enable genome-wide profiling of carbohydrate-active enzymes that are distinct and correlated with the fungal mode of infection. Importantly, G. boninense NJ3 harbored a distinct set of cell wall degrading and polysaccharide depolymerization enzymes that were suited for infecting monocot oil palm host through hemibiotrophic lifestyle.

\section{Potential pathogenicity genes among CAZymes of $G$. boninense $\mathrm{NJ3}$}

Comparative CAZymes analysis of the selected of phytopathogens indicated the correlation between the fungal nutritional strategy with the profiles of carbohydrate-active enzymes essential for plant host cell wall degradation and nutrient consumption. Considering the lack of information genes related to the pathogenicity of $G$. boninense, further genome-wide analysis of the fungal genome was carried out using the protein sequences in the Pathogen-Host Interaction Database (PHI database) and functionally classified according to molecular function, biological process and cellular component via WEGO analysis. A total of 5,099 annotated PHI genes were obtained from the WEGO analysis of which membrane (1682, 24.8\%) and metabolic process $(2903,42.8 \%)$ were represented the highest in respective cellular component and biological process categories (Fig. 4). In molecular function category, the PHI genes were predominantly annotated with catalytic activity $(3337,49.2 \%)$ including CAZymes-related polygalacturonase (GO:0004650), cellulase (GO:0008810) and endo-1,4-beta-xylanase (GO:0031176).

Considering the prevalence of carbohydrate-active enzymes and the high percentage of PHI genes with hydrolase activity, we hypothesized that some of the CAZymes may directly involve in plant pathogenesis via cell wall degradation by the secreted enzymes. As shown in Table 1, several genes of G. boninense NJ3 were shown to share PHI homologs with lignin depolymerization and cell wall degrading enzymes specifically pectic-acting polygalacturonase (PG)-coding homolog gene (PHI id:4879), endo-1,4-beta-xylanase GH10 (PHI id:2209), $\beta$ glucanase Eng1 (PHI id:6265) and laccase LCC2 (PHI id:552). CWDEs including pectinase, glycosyl hydrolase and laccase mainly serve as primary weaponry for fungal attack causing the plant cell wall becoming less compact and more permeable for consequent digestion by cellulase and hemicellulase enzymes (Chu et al., 2015). Importantly, PG is one of the first enzymes secreted by pathogenic fungi upon contact with plant cell wall and these pectinases have been widely studied for their role in plant pathogenesis especially necrosis and rotting in the infected plants (De Lorenzo \& Ferrari, 2002; Kubicek, Starr \& Glass, 2014). This finding corroborated 
439 with the reported polygalacturonase activities from the transcriptome profile of $G$. boninense-

440 infected oil palm (Elaeis guineensis) whereby PG transcript was shown to be elevated as

441 compared to none observed in control unaffected oil palm (Ho et al., 2016). It can be postulated

442 that pectin-acting PG work synergistically with hemicellulases for Ganoderma infection in

443 similar fashion to necrotrophic infection and virulence of many phytopathogens including

444 Fusarium spp., the main causative agents of vascular wilt and head blight diseases in important

445 crops (Gómez-Gómez et al., 2002; Chen et al., 2012b; Paccanaro et al., 2017). Hemi-cellulosic

446 digestion activities of $G$. boninense were previously demonstrated to assist the fungal growth on

447 oil palm hence supporting the association of these PHI genes as potential pathogenicity factors in

448 oil palm infection ( Surendran et al., 2017; Surendran et al., 2018).

449 On the other hand, no cutinase (CE5) homolog was found from the CAZymes and

450 PHIbase analysis of $G$. boninense $\mathrm{NJ} 3$ suggesting the lack of cutinase-mediated cell wall

451 modification during wood-decaying process which may be compensated by the high numbers of

452 oxidative AAs and hydrolytic GHs found in the Ganoderma spp. examined in this study (Table

453 S2). CE5 was found not prevalent in wood-decaying basidiomycetes including pathogenic $H$.

454 irregulare and Fomitiporia mediterranea which harbored multiple copies of lignolytic

455 peroxidase enzymes (Floudas et al., 2012; Zhao et al., 2013). Expression of cutinase was also

456 reported to be non-essential during pathogenesis of other necrotizing pathogens such as $F$. solani

457 f. sp. pisi and Botrytis cinerea (van Kan et al., 1997; Stahl \& Schafer, 2007; Zhao et al., 2013).

458 Combined actions of ligninolytic and cellulolytic enzymes including laccase and endoglucanase

459 were previously shown to be directly involved in the wood decaying and infection processes of

460 wheat and cacao by necrotrophic F. graminearum and Moniliophthora roreri, respectively

461 (Zhang et al., 2012; Meinhardt et al., 2014). Transcriptome analysis of Ganoderma infected-oil

462 palm seedling demonstrated the presence of multiple copies of laccase transcripts as compared to

463 none observed in the sample of beneficial fungus, T. harzianum, indicating the important role of

464 cell wall degradation in oil palm infection (Ho et al., 2016, 2018). The identification of these cell

465 wall degrading PHI genes further supported the hemibiotrophic mode of infection of $G$.

466 boninense conferred by fungal genotypic capabilities to produce a plethora of carbohydrate-

467 acting enzymes. Overall, the comparative genome analysis employed in this study succeeded in

468 characterizing carbohydrate-active enzymes and identifying CWDE genes that are involved in

469 plant cell wall degradation and pathogenesis of $G$. boninense. Further genome analysis of $G$.

470 boninense strains can be carried out with the recent report of draft genome of G. boninense G3

471 strain isolated from Indonesian region (Utomo et al., 2018). Correlation between the fungal

472 pathogenicity with CWDE production and other factors can be further validated via targeted

473 transcriptome analysis and gene expression profiling of targeted genes (Isaac et al., 2018).

474 Functional studies of the cell wall degrading enzymes in $G$. boninense shall be pursued for

475 greater understanding on the essentiality of the enzymatic capacity in the fungal pathogenesis.

476

477 CONCLUSIONS 
478 In this study, comparative genome analysis succeeded in the identification of carbohydrate-

479

480

481

482

483

484

485

486

487

488

489

490

491

492

493

494

495

496

497

498

499

500

501

502

503

504

505

506

507

508

509

510

511

512

513

514

515

516

517

518

519

520

acting and cell wall degrading enzymes in hemibiotrophic $G$. boninense NJ3. The pathogenic $G$. boninense $\mathrm{NJ} 3$ genome contained an abundant amount of CAZymes and shared many similar sets of CAZymes to closely-related G. lucidum of which the differences between the gene sets can be attributed to the different nutritional strategy of either Ganoderma spp. Necrotizing fungal pathogens including $G$. boninense NJ3 exhibited distinct CAZymes profiles as compared to the non-necrotizing counterparts which can be correlated with host preference and parasitic lifestyles. Several CWDE-related genes were identified from PHI analysis including polygalacturonase and laccase which could directly contribute to the fungal pathogenesis especially through degradation of the plant cell wall. These findings provide fundamental knowledge on the fungal genetic ability and capacity to secrete polysaccharide and cell wall degrading enzymes. Greater insight on the fungal phenotype can be obtained through future studies involving functional and gene expression analysis of specific genes in the fungal carbohydrate metabolism.

\section{ACKNOWLEDGEMENTS}

The authors would like to thank Goh Yit Kheng from Applied Agricultural Resources Sdn Bhd for his insightful revision during the manuscript preparation.

\section{REFERENCES}

Bahari MNA, Sakeh NM, Abdullah SNA, Ramli RR, Kadkhodaei S. 2018. Transcriptome profiling at early infection of Elaeis guineensis by Ganoderma boninense provides novel insights on fungal transition from biotrophic to necrotrophic phase. BMC Plant Biology 18:377.

Blackman LM, Cullerne DP, Hardham AR. 2014. Bioinformatic characterisation of genes encoding cell wall degrading enzymes in the Phytophthora parasitica genome. BMC Genomics 15:785.

Boh B. 2013. Ganoderma lucidum: A potential for biotechnological production of anti-cancer and immunomodulatory drugs. Recent Patents on Anti-Cancer Drug Discovery 8(3):255287.

Bravo Ruiz G, Di Pietro A, Roncero MIG. 2016. Combined action of the major secreted exo- and endopolygalacturonases is required for full virulence of Fusarium oxysporum. Molecular Plant Pathology 17(3):339-353.

Brito N, Espino JJ, González C. 2006. The endo- $\beta-1,4-x y l a n a s e ~ X y n 11$ a is required for virulence in Botrytis cinerea. Molecular Plant-Microbe Interactions 19:25-32.

Chang HX, Yendrek CR, Caetano-Anolles G, Hartman GL. 2016. Genomic characterization of plant cell wall degrading enzymes and in silico analysis of xylanases and polygalacturonases of Fusarium virguliforme. BMC Microbiology 16:147.

Chen ZY, Goh YK, Goh YK, Goh KJ. 2017. Life expectancy of oil palm (Elaeis guineensis ) infected by Ganoderma boninense in coastal soils, Malaysia: a case study. Archives of Phytopathology and Plant Protection 50:598-612.

Chen W, Xie T, Shao Y, Chen F. 2012a. Phylogenomic relationships between amylolytic enzymes from 85 strains of fungi. PLOS ONE 7:e49679. 
521

522

523

524

525

526

527

528

529

530

531

532

533

534

535

536

537

538

539

540

541

542

543

544

545

546

547

548

549

550

551

552

553

554

555

556

557

558

559

560

561

562

563

564

565

566

Chen S, Xu J, Liu C, Zhu Y, Nelson DR, Zhou S, Li C, Wang L, Guo X, Sun Y, Luo H, Li Y, Song J, Henrissat B, Levasseur A, Qian J, Li J, Luo X, Shi L, He L, Xiang L, Xu X, Niu Y, Li Q, Han M V, Yan H, Zhang J, Chen H, Lv A, Wang Z, Liu M, Schwartz DC, Sun C. 2012b. Genome sequence of the model medicinal mushroom Ganoderma lucidum. Nature Communications 3:913.

Chong KP, Dayou J, Alexander A. 2017. Pathogenic nature of Ganoderma boninense and basal stem rot disease. In: Springer, Cham, 5-12.

Chu J, Li WF, Cheng W, Lu M, Zhou KH, Zhu HQ, Li FG, Zhou CZ. 2015. Comparative analyses of secreted proteins from the phytopathogenic fungus Verticillium dahliae in response to nitrogen starvation. BBA - Proteins and Proteomics 1854:437-448.

Collins C, Keane TM, Turner DJ, O'Keeffe G, Fitzpatrick DA, Doyle S. 2013. Genomic and proteomic dissection of the ubiquitous plant pathogen, Armillaria mellea: Toward a new infection model system. Journal of Proteome Research 12(6):2552-2570.

De Lorenzo G, Ferrari S. 2002. Polygalacturonase-inhibiting proteins in defense against phytopathogenic fungi. Current Opinion in Plant Biology 5(4):295-299.

Duplessis S, Cuomo CA, Lin YC, Aerts A, Tisserant E, Veneault-Fourrey C, Joly DL, Hacquard S, Amselem J, Cantarel BL, Chiu R, Coutinho PM, Feau N, Field M, Frey P, Gelhaye E, Goldberg J, Grabherr MG, Kodira CD, Kohler A, Kues U, Lindquist EA, Lucas SM, Mago R, Mauceli E, Morin E, Murat C, Pangilinan JL, Park R, Pearson M, Quesneville H, Rouhier N, Sakthikumar S, Salamov AA, Schmutz J, Selles B, Shapiro H, Tanguay P, Tuskan GA, Henrissat B, Van de Peer Y, Rouze P, Ellis JG, Dodds PN, Schein JE, Zhong S, Hamelin RC, Grigoriev IV, Szabo LJ, Martin F. 2011. Obligate biotrophy features unraveled by the genomic analysis of rust fungi. Proceedings of the National Academy of Sciences 108: 9166-917.

Duplessis S, Major I, Martin F, Séguin A. 2009. Poplar and pathogen interactions: insights from populus genome-wide analyses of resistance and defense gene families and gene expression profiling. Critical Reviews in Plant Sciences 28:309-334.

Floudas D, Binder M, Riley R, Barry K, Blanchette RA, Henrissat B, Martínez AT, Otillar R, Spatafora JW, Yadav JS, Aerts A, Benoit I, Boyd A, Carlson A, Copeland A, Coutinho PM, de Vries RP, Ferreira P, Findley K, Foster B, Gaskell J, Glotzer D, Górecki P, Heitman J, Hesse C, Hori C, Igarashi K, Jurgens JA, Kallen N, Kersten P, Kohler A, Kües U, Kumar TKA, Kuo A, LaButti K, Larrondo LF, Lindquist E, Ling A, Lombard V, Lucas S, Lundell T, Martin R, McLaughlin DJ, Morgenstern I, Morin E, Murat C, Nagy LG, Nolan M, Ohm RA, Patyshakuliyeva A, Rokas A, Ruiz-Dueñas FJ, Sabat G, Salamov A, Samejima M, Schmutz J, Slot JC, St John F, Stenlid J, Sun H, Sun S, Syed K, Tsang A, Wiebenga A, Young D, Pisabarro A, Eastwood DC, Martin F, Cullen D, Grigoriev IV, Hibbett DS. 2012. The Paleozoic origin of enzymatic lignin decomposition reconstructed from 31 fungal genomes. Science 336:1715-1719.

Garfoot AL, Shen Q, Wüthrich M, Klein BS, Rappleye CA. 2016. The Eng1 $\beta$-glucanase enhances histoplasma virulence by reducing $\beta$-glucan exposure. American Society for Microbiology 7:1-9.

Gawade DB, Perane RR, Suryawanshi AP. Deokar CD. 2017. Extracellular enzymes activity determining the virulence of Rhizoctonia bataticola, causing root rot in soybean. Physiological and Molecular Plant Pathology 100:49-56.

Goh KM, Ganeson M, Supramaniam CV. 2014. Infection potential of vegetative incompatible Ganoderma boninense isolates with known ligninolytic enzyme production. African Journal 
567

568

569

570

571

572

573

574

575

576

577

578

579

580

581

582

583

584

585

586

587

588

589

590

591

592

593

594

595

596

597

598

599

600

601

602

603

604

605

606

607

608

609

610

611

612

of Biotechnology 13:1056-1066.

Gómez-Gómez E, Ruíz-Roldán MC, Di Pietro A, Roncero MIG, Hera C. 2002. Role in pathogenesis of two endo-beta-1,4-xylanase genes from the vascular wilt fungus Fusarium oxysporum. Fungal genetics and biology 35:213-222.

Grigoriev IV, Nikitin R, Haridas S, Kuo A, Ohm R, Otillar R, Riley R, Salamov A. Zhao X, Korzeniewski F, Smirnova T, Nordberg H, Dubchak I, Shabalov I. 2014. MycoCosm portal: gearing up for 1000 fungal genomes. Nucleic Acids Research 42:D699-D704.

Hatakka A. 1994. Lignin-modifying enzymes from selected white-rot fungi: production and role from in lignin degradation. FEMS Microbiology Reviews 13:125-135.

Ho CL, Tan YC, Yeoh KA, Ghazali AK, Yee WY, Hoh CC. 2016. De novo transcriptome analyses of host-fungal interactions in oil palm (Elaeis guineensis Jacq.). BMC Genomics 17:66.

Ho CL, Tan YC, Yeoh KA, Lee WK, Ghazali AK, Yee WY, Hoh CC. 2018. Transcriptional response of oil palm (Elaeis guineensis Jacq.) inoculated simultaneously with both Ganoderma boninense and Trichoderma harzianum. Plant Gene 13:56-63.

Horbach R, Navarro-Quesada AR, Knogge W, Deising HB. 2011. When and how to kill a plant cell: Infection strategies of plant pathogenic fungi. Journal of Plant Physiology.

$\mathrm{Hu}$ Y, Ahmed S, Li J, Luo B, Gao Z, Zhang Q, Li X, Hu X. 2017. Improved ganoderic acids production in Ganoderma lucidum by wood decaying components. Scientific Reports 7:46623.

Hushiarian R, Yusof NA, Dutse SW. 2013. Detection and control of Ganoderma boninense: strategies and perspectives. SpringerPlus 2:555.

Isaac IL, Walter AWCY, Bakar MFA, Idris AS, Bakar FDA, Bharudin I, Murad AMA. 2018. Transcriptome datasets of oil palm pathogen Ganoderma boninense. Data in brief 17:11081111.

Islam M, Haque M, Islam M, Emdad E, Halim A, Hossen QM, Hossain M, Ahmed B, Rahim S, Rahman M, Alam M, Hou S, Wan X, Saito JA, Alam M. 2012. Tools to kill: Genome of one of the most destructive plant pathogenic fungi Macrophomina phaseolina. BMC Genomics 13:493.

Janusz G, Pawlik A, Sulej J, Świderska-Burek U, Jarosz-Wilkolazka A, Paszczyński A. 2017. Lignin degradation: Microorganisms, enzymes involved, genomes analysis and evolution. FEMS Microbiology Reviews 41:941-962.

Jones RW, Ospina-Giraldo M. 2011. Novel cellulose-binding-domain protein in phytophthora is cell wall localized. PLoS ONE 6(8):e23555.

Jumali SS, Ismail S. 2017. Ganoderma boninense efficacy in delignifying oil palm empty fruit bunches. Pertanika Journal of Science \& Technology 25:1-8.

Kämper J, Kahmann R, Bölker M, Ma LJ, Brefort T, Saville BJ, Banuett F, Kronstad JW, Gold SE, Müller O, Perlin MH, Wösten HAB, de Vries R, Ruiz-Herrera J, Reynaga-Peña CG, Snetselaar K, McCann M, Pérez-Martín J, Feldbrügge M, Basse CW, Steinberg G, Ibeas JI, Holloman W, Guzman P, Farman M, Stajich JE, Sentandreu R, González-Prieto JM, Kennell JC, Molina L, Schirawski J, Mendoza-Mendoza A, Greilinger D, Münch K, Rössel N, Scherer M, Vraneš M, Ladendorf O, Vincon V, Fuchs U, Sandrock B, Meng S, Ho ECH, Cahill MJ, Boyce KJ, Klose J, Klosterman SJ, Deelstra HJ, Ortiz-Castellanos L, Li W, Sanchez-Alonso P, Schreier PH, Häuser-Hahn I, Vaupel M, Koopmann E, Friedrich G, Voss H, Schlüter T, Margolis J, Platt D, Swimmer C, Gnirke A, Chen F, Vysotskaia V, Mannhaupt G, Güldener U, Münsterkötter M, Haase D, Oesterheld M, Mewes HW, Mauceli 
613

614

615

616

617

618

619

620

621

622

623

624

625

626

627

628

629

630

631

632

633

634

635

636

637

638

639

640

641

642

643

644

645

646

647

648

649

650

651

652

653

654

655

656

657

658

EW, DeCaprio D, Wade CM, Butler J, Young S, Jaffe DB, Calvo S, Nusbaum C, Galagan J, Birren BW. 2006. Insights from the genome of the biotrophic fungal plant pathogen Ustilago maydis. Nature 444:97-101.

Kang Z, Buchenauer H. 2000. Ultrastructural and cytochemical studies on cellulose, xylan and pectin degradation in wheat spikes infected by Fusarium culmorum. Journal of Phytopathology 148: 263- 275.

King BC, Waxman KD, Nenni NV, Walker LP, Bergstrom GC, Gibson DM. 2011. Arsenal of plant cell wall degrading enzymes reflects host preference among plant pathogenic fungi. Biotechnology for Biofuels 4:4.

Klosterman SJ, Subbarao KV, Kang S, Veronese P, Gold SE, Thomma BPHJ, Chen Z, Henrissat B, Lee YH, Park J, Garcia-Pedrajas MD, Barbara DJ, Anchieta A, de Jonge R, Santhanam P, Maruthachalam K, Atallah Z, Amyotte SG, Paz Z, Inderbitzin P, Hayes RJ, Heiman DI, Young S, Zeng Q, Engels R, Galagan J, Cuomo CA, Dobinson KF, Ma LJ. 2011. Comparative genomics yields insights into niche adaptation of plant vascular wilt pathogens. PLoS Pathogens 7(7):e1002137.

Koch RA, Wilson AW, Séné O, Henkel TW, Aime MC. 2017. Resolved phylogeny and biogeography of the root pathogen Armillaria and its gasteroid relative, Guyanagaster. BMC Evolutionary Biology 17:33.

Kubicek CP, Starr TL, Glass NL. 2014. Plant cell wall-degrading enzymes and their secretion in plant-pathogenic fungi. Annual Review of Phytopathology 52:427-451.

Larroque M, Barriot R, Bottin A, Barre A, Rougé P, Dumas B, Gaulin E. 2012. The unique architecture and function of cellulose-interacting proteins in oomycetes revealed by genomic and structural analyses. BMC Genomics 13:605.

Levasseur A, Drula E, Lombard V, Coutinho PM, Henrissat B. 2013. Expansion of the enzymatic repertoire of the CAZy database to integrate auxiliary redox enzymes. Biotechnology for Biofuels 6(1):41.

Li S, Darwish O, Alkharouf NW, Musungu B, Matthews BF. 2017. Analysis of the genome sequence of Phomopsis longicolla: A fungal pathogen causing Phomopsis seed decay in soybean. BMC Genomics.

Liu D, Gong J, Dai W, Kang X, Huang Z, Zhang HM, Liu W, Liu L, Ma J, Xia Z, Chen Y, Chen Y, Wang D, Ni P, Guo AY, Xiong X. 2012. The genome of Ganoderma lucidum provide insights into triterpense biosynthesis and wood degradation. PLOS ONE 7:e36146.

Looi HK, Toh YF, Yew SM, Na SL, Tan YC, Chong PS, Khoo JS, Yee WY, Ng KP, Kuan CS. 2017. Genomic insight into pathogenicity of dematiaceous fungus Corynespora cassiicola. PeerJ 5:e2841.

Lowe RGT, Cassin A, Grandaubert J, Clark BL, Van De Wouw AP, Rouxel T, Howlett BJ. 2014. Genomes and transcriptomes of partners in plant-fungal- interactions between canola (Brassica napus) and two Leptosphaeria species. PLoS ONE. 9(7): e103098.

Loyd AL, Barnes CW, Held BW, Schink MJ, Smith ME, Smith JA, Blanchette RA. 2018. Elucidating "lucidum": Distinguishing the diverse laccate Ganoderma species of the United States. PLOS ONE 13(7):e0199738.

Lyu X, Shen C, Fu Y, Xie J, Jiang D, Li G, Cheng J. 2015. Comparative genomic and transcriptional analyses of the carbohydrate-active enzymes and secretomes of phytopathogenic fungi reveal their significant roles during infection and development. Scientific Reports 5:15565.

M'Barek SB, Cordewener JHG, van der Lee TAJ, America AHP, Mirzadi Gohari A, Mehrabi R,

PeerJ reviewing PDF | (2018:12:33674:3:0:NEW 14 Oct 2019) 
659

660

661

662

663

664

665

666

667

668

669

670

671

672

673

674

675

676

677

678

679

680

681

682

683

684

685

686

687

688

689

690

691

692

693

694

695

696

697

698

699

700

701

702

703

704

Hamza S, de Wit PJGM, Kema GHJ. 2015. Proteome catalog of Zymoseptoria tritici captured during pathogenesis in wheat. Fungal Genetics and Biology 79:42-53.

Meinhardt LW, Costa GG, Thomazella DPT, Teixeira PJPL, Carazzolle M, Schuster SC, Carlson JE, Guiltinan MJ, Mieczkowski P, Farmer A, Ramaraj T, Crozier J, Davis RE, Shao J, Melnick RL, Pereira GAG, Bailey BA. 2014. Genome and secretome analysis of the hemibiotrophic fungal pathogen, Moniliophthora roreri, which causes frosty pod rot disease of cacao: mechanisms of the biotrophic and necrotrophic phases. BMC Genomics 15:164.

Mello BL, Polikarpov I. 2014. Family 1 carbohydrate binding-modules enhance saccharification rates. AMB Express 4:1-6.

Mendgen K., Hahn M. 2002. Plant infection and the establishment of fungal biotrophy. Trends in Plant Science 7:352-356.

Mercière M, Laybats A, Carasco-Lacombe C, Tan JS, Klopp C, Durand-Gasselin T, Alwee SSRS, Camus-Kulandaivelu L, Breton F. 2015. Identification and development of new polymorphic microsatellite markers using genome assembly for Ganoderma boninense, causal agent of oil palm basal stem rot disease. Mycological Progress 14:103.

Mondego JMC, Carazzolle MF, Costa GGL, Formighieri EF, Parizzi LP, Rincones J, Cotomacci C, Carraro DM, Cunha AF, Carrer H, Vidal RO, Estrela RC, García O, Thomazella DPT, de Oliveira BV, Pires ABL, Rio MC, Araújo MRR, de Moraes MH, Castro LAB, Gramacho KP, Gonçalves MS, Neto JPM, Neto AG, Barbosa LV, Guiltinan MJ, Bailey BA, Meinhardt LW, Cascardo JCM, Pereira GAG. 2008. A genome survey of Moniliophthora perniciosa gives new insights into Witches' Broom Disease of cacao. BMC Genomics 9:548.

Nguyen QB, Itoh K, Van Vu B, Tosa Y, Nakayashiki H. 2011. Simultaneous silencing of endo$\beta-1,4$ xylanase genes reveals their roles in the virulence of Magnaporthe oryzae. Molecular Microbiology 81:1008-1019.

Nusaibah SA, Siti Nor Akmar A, Idris AS, Sariah M, Mohamad Pauzi Z. 2016. Involvement of metabolites in early defense mechanism of oil palm (Elaeis guineensis Jacq.) against Ganoderma disease. Plant Physiology and Biochemistry 109:156-165.

O'Connell RJ, Thon MR, Hacquard S, Amyotte SG, Kleemann J, Torres MF, Damm U, Buiate EA, Epstein L, Alkan N, Altmüller J, Alvarado-Balderrama L, Bauser CA, Becker C, Birren BW, Chen Z, Choi J, Crouch JA, Duvick JP, Farman MA, Gan P, Heiman D, Henrissat B, Howard RJ, Kabbage M, Koch C, Kracher B, Kubo Y, Law AD, Lebrun MH, Lee YH, Miyara I, Moore N, Neumann U, Nordström K, Panaccione DG, Panstruga R, Place M, Proctor RH, Prusky D, Rech G, Reinhardt R, Rollins JA, Rounsley S, Schardl CL, Schwartz DC, Shenoy N, Shirasu K, Sikhakolli UR, Stüber K, Sukno SA, Sweigard JA, Takano Y, Takahara H, Trail F, Van Der Does HC, Voll LM, Will I, Young S, Zeng Q, Zhang J, Zhou S, Dickman MB, Schulze-Lefert P, Ver Loren Van Themaat E, Ma LJ, Vaillancourt LJ. 2012. Lifestyle transitions in plant pathogenic Colletotrichum fungi deciphered by genome and transcriptome analyses. Nature Genetics 44(9): 1060-1065.

Olson Å, Aerts A, Asiegbu F, Belbahri L, Bouzid O, Broberg A, Canbäck B, Coutinho PM, Cullen D, Dalman K, Deflorio G, van Diepen LTA, Dunand C, Duplessis S, Durling M, Gonthier P, Grimwood J, Fossdal CG, Hansson D, Henrissat B, Hietala A, Himmelstrand K, Hoffmeister D, Högberg N, James TY, Karlsson M, Kohler A, Kües U, Lee YH, Lin YC, Lind M, Lindquist E, Lombard V, Lucas S, Lundén K, Morin E, Murat C, Park J, Raffaello T, Rouzé P, Salamov A, Schmutz J, Solheim H, Ståhlberg J, Vélëz H, de Vries RP, Wiebenga A, Woodward S, Yakovlev I, Garbelotto M, Martin F, Grigoriev IV, Stenlid J. 2012. Insight into trade-off between wood decay and parasitism from the genome of a

PeerJ reviewing PDF | (2018:12:33674:3:0:NEW 14 Oct 2019) 
705

706

707

708

709

710

711

712

713

714

715

716

717

718

719

720

721

722

723

724

725

726

727

728

729

730

731

732

733

734

735

736

737

738

739

740

741

742

743

744

745

746

747

748

749

750

fungal forest pathogen. New Phytologist 194:1001-1013.

Ospina-Giraldo MD, McWalters J, Seyer L. 2010. Structural and functional profile of the carbohydrate esterase gene complement in Phytophthora infestans. Current Genetics 56:495-506.

Paccanaro MC, Sella L, Castiglioni C, Giacomello F, Martínez-Rocha AL, D’Ovidio R, Schäfer W, Favaron F. 2017. Synergistic effect of different plant cell wall-degrading enzymes is important for virulence of Fusarium graminearum. Molecular Plant-Microbe Interactions 30.

Paterson RRM. 2007. Ganoderma disease of oil palm-A white rot perspective necessary for integrated control. Crop Protection 26:1369-1376.

Rees RW. 2006. Ganoderma stem rot of oil palm (Elaeis guineensis): mode of infection, epidemiology and biological control. Bath, UK: University of Bath, $\mathrm{PhD}$ thesis.

Rees RW, Flood J, Hasan Y, Potter U, Cooper RM. 2009. Basal stem rot of oil palm (Elaeis guineensis); Mode of root infection and lower stem invasion by Ganoderma boninense. Plant Pathology 58:982-989.

Ross-Davis AL, Stewart JE, Hanna JW, Kim MS, Knaus BJ, Cronn R, Rai H, Richardson BA, McDonald GI, Klopfenstein NB. 2013. Transcriptome of an Armillaria root disease pathogen reveals candidate genes involved in host substrate utilization at the host-pathogen interface. Forest Pathology 43:468-477.

Sahebi M, Hanafi MM, van Wijnen AJ, Akmar ASN, Azizi P, Idris AS, Taheri S, Foroughi M. 2017. Profiling secondary metabolites of plant defence mechanisms and oil palm in response to Ganoderma boninense attack. International Biodeterioration and Biodegradation 122:151-164.

Sahebi M, Hanafi MM, Wong MY, Idris AS, Azizi P, Jahromi MF, Shokryazdan P, Abiri R, Mohidin H. 2015. Towards immunity of oil palm against Ganoderma fungus infection. Acta Physiologiae Plantarum 37:195.

Schouten A, Wagemakers L, Stefanato FL, Van der Kaaij RM, Van Kan JAL. 2002. Resveratrol acts as a natural profungicide and induces self-intoxication by a specific laccase. Molecular Microbiology 43:883-894.

Silva CMMD, Melo IS, Oliveira PR. 2005. Ligninolytic enzyme production by Ganoderma spp. Enzyme and Microbial Technology 37:324-329.

Sipos G, Prasanna AN, Walter MC, O’Connor E, Bálint B, Krizsán K, Kiss B, Hess J, Varga T, Slot J, Riley R, Bóka B, Rigling D, Barry K, Lee J, Mihaltcheva S, Labutti K, Lipzen A, Waldron R, Moloney NM, Sperisen C, Kredics L, Vágvölgyi C, Patrignani A, Fitzpatrick D, Nagy I, Doyle S, Anderson JB, Grigoriev IV, Güldener U, Münsterkötter M, Nagy LG. 2017. Genome expansion and lineage-specific genetic innovations in the forest pathogenic fungi Armillaria. Nature Ecology and Evolution 1(12):1931-1941.

Sista Kameshwar AK, Qin W. 2018. Understanding the structural and functional properties of carbohydrate esterases with a special focus on hemicellulose deacetylating acetyl xylan esterases. Mycology 9(4):273-295.

Somai-Jemmali L, Siah A, Harbaoui K, Fergaoui S, Randoux B, Magnin-Robert M, Halama P, Reignault P, Hamada W. 2017. Correlation of fungal penetration, CWDE activities and defense-related genes with resistance of durum wheat cultivars to Zymoseptoria tritici. Physiological and Molecular Plant Pathology 100:117-125.

Stahl DJ, Schafer W. 1992. Cutinase is not required for fungal pathogenicity on pea. The Plant Cell. 4(6): 621-629. 
751

752

753

754

755

756

757

758

759

760

761

762

763

764

765

766

767

768

769

770

771

772

773

774

775

776

777

778

779

780

781

782

783

784

785

786

787

788

789

790

791

792

793

794

795

796

Sulaiman S, Syamimi Yusoff N, Joon Sheong T, Yang Ping L. 2018. Deciphering the pangenome of Ganoderma sp. to depict potential genomic components that contribute to Ganoderma boninense pathogenicity. Malaysian Applied Biology 47(5): 71-80.

Surendran A, Siddiqui Y, Saud HM, Manickam N. 2017. The antagonistic effect of phenolic compounds on ligninolytic and cellulolytic enzymes of Ganoderma boninense, causing basal stem rot in oil palm. International Journal of Agriculture And Biology 19 (6): 14371446

Surendran A, Siddiqui Y, Ali NS, Manickam S. 2018. Inhibition and kinetic studies of celluloseand hemicellulose-degrading enzymes of Ganoderma boninense by naturally occurring phenolic compounds. Journal of Applied Microbiology 124:1544-1555.

Utomo C, Tanjung ZA, Aditama R, Buana RFN, Pratomo ADM, Tryono R, Liwang T. 2018. Draft genome sequence of the phytopathogenic fungus Ganoderma boninense, the causal agent of basal stem rot disease on oil palm. Genome Announcements 6:1-2.

van Kan JAL, van't Klooster JW, Wagemakers CAM, Dees DCT, van der Vlugt-Bergmans CJB. 1997. Cutinase A of Botrytis cinerea is expressed, but not essential, during penetration of gerbera and tomato. Molecular Plant-Microbe Interactions 10:30-38.

Várnai A, Mäkelä MR, Djajadi DT, Rahikainen J, Hatakka A, Viikari L. 2014. Carbohydratebinding modules of fungal cellulases. Occurrence in nature, function, and relevance in industrial biomass conversion. Advances in Applied Microbiology 88:103-165.

Wanjiru WM, Zhensheng K, Buchenauer H. 2002. Importance of cell wall degrading enzymes produced by Fusarium graminearum during infection of wheat heads. European Journal of Plant Pathology 108:803-810.

Wu GS, Guo JJ, Bao JL, Li XW, Chen XP, Lu JJ, Wang YT. 2013. Anti-cancer properties of triterpenoids isolated from Ganoderma lucidum - a review. Expert Opinion on Investigational Drugs 22:981-992.

Xu JW, Xu YN, Zhong JJ. 2012. Enhancement of ganoderic acid accumulation by overexpression of an N-terminally truncated 3-hydroxy-3-methylglutaryl coenzyme A reductase gene in the basidiomycete Ganoderma lucidum. Applied and Environmental Microbiology 78(22):7968-7976.

Ye J, Fang L, Zheng H, Zhang Y, Chen J, Zhang Z, Wang J, Li S, Li R, Bolund L, Wang J. 2006. WEGO: A web tool for plotting GO annotations. Nucleic Acids Research 34:293-297.

Yu GJ, Wang M, Huang J, Yin YL, Chen YJ, Jiang S, Jin YX, Lan XQ, Wong BHC, Liang Y, Sun H. 2012. Deep insight into the Ganoderma lucidum by comprehensive analysis of its transcriptome. PLoS ONE 7:e44031.

Zaccaron AZ, Bluhm BH. 2017. The genome sequence of Bipolaris cookei reveals mechanisms of pathogenesis underlying target leaf spot of sorghum. Scientific Reports 7(1):17217.

Zhang J, Bruton BD, Biles CL. 2014. Cell wall-degrading enzymes of Didymella bryoniae in relation to fungal growth and virulence in cantaloupe fruit. European Journal of Plant Pathology 139(4):749-761.

Zhang XW, Jia LJ, Zhang Y, Jiang G, Li X, Zhang D, Tang WH. 2012. In planta stage-specific fungal gene profiling elucidates the molecular strategies of Fusarium graminearum growing inside wheat coleoptiles. The Plant Cell 24:5159-5176.

Zhao Z, Liu H, Wang C, Xu JR. 2013. Comparative analysis of fungal genomes reveals different plant cell wall degrading capacity in fungi. BMC Genomics 14:274.

Zheng A, Lin R, Zhang D, Qin P, Xu L, Ai P, Ding L, Wang Y, Chen Y, Liu Y, Sun Z, Feng H, Liang X, Fu R, Tang C, Li Q, Zhang J, Xie Z, Deng Q, Li S, Wang S, Zhu J, Wang L, Liu

PeerJ reviewing PDF | (2018:12:33674:3:0:NEW 14 Oct 2019) 
797 H, Li P. 2013. The evolution and pathogenic mechanisms of the rice sheath blight pathogen. $798 \quad$ Nature Communications 4:1424.

799 Zhou XW, Cong WR, Su KQ, Zhang YM. 2013. Ligninolytic enzymes from Ganoderma spp:

800 Current status and potential applications. Critical Reviews in Microbiology 39:416-426.

801 Zhou S, Zhang J, Ma F, Tang C, Tang Q, Zhang X. 2018. Investigation of lignocellulolytic

802 enzymes during different growth phases of Ganoderma lucidum strain G0119 using

803 genomic, transcriptomic and secretomic analyses. PLOS ONE 13:e0198404.

804 


\section{Figure 1}

Comparison of carbohydrate-active enzymes (CAZymes) in Ganoderma spp.

Overview of CAZymes profile in (a) G. boninense NJ3 and (b) G. lucidum. Abbreviations: GH Glycoside hydrolase, CE Carbohydrate esterase, PL polysaccharide lyase, CBM carbohydrate binding module, AA auxiliary activity, GT glycosyltransferase.

a

\section{G. boninense}

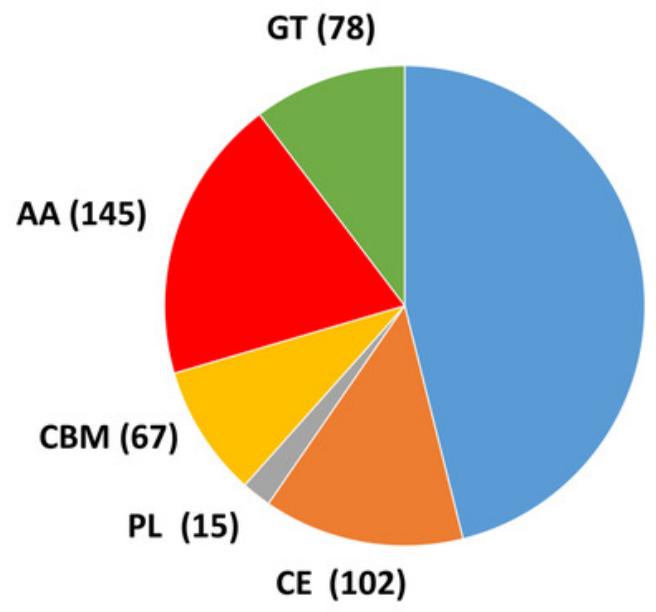

b

G. Iucidum

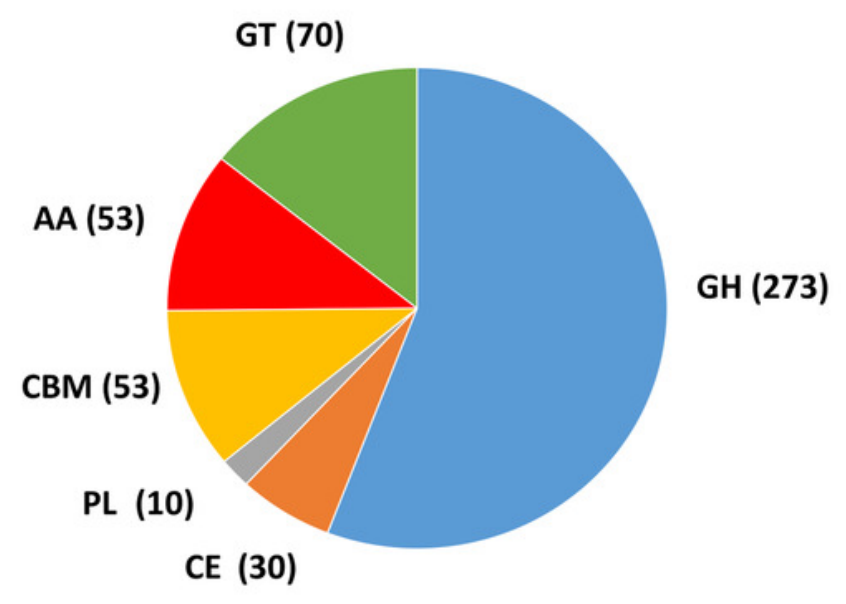


Figure 2

Profiling of CWDEs in selected phytopathogenic Basidiomycota fungi.

Profile of (a) common GH, (b) CE and (c) PL in the pathogenic fungi. Abbreviations: GH Glycoside hydrolase, CE Carbohydrate esterase, PL polysaccharide lyase.

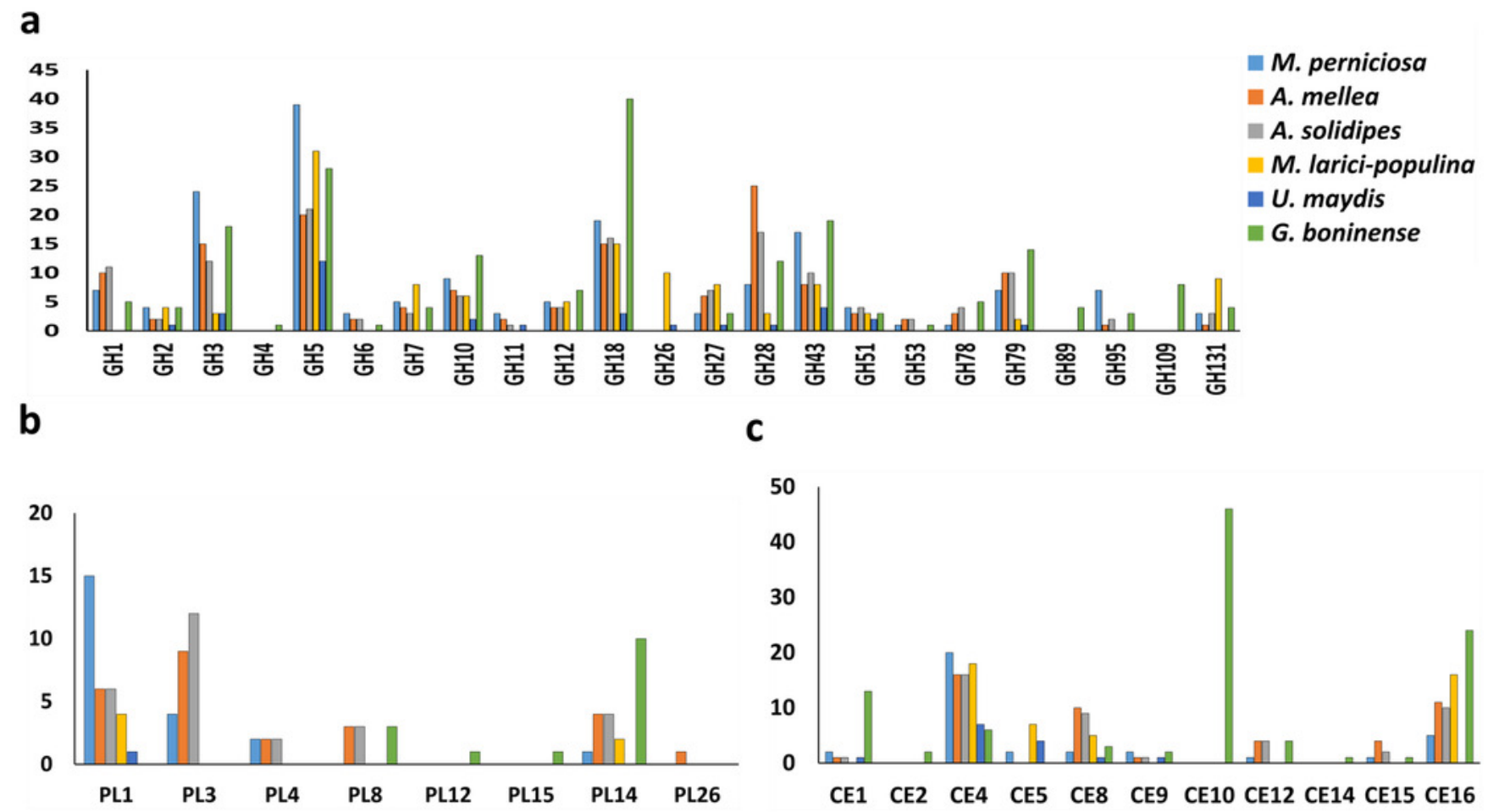


Figure 3

Profiles of carbohydrate-active enzymes (CAZymes) in phytopathogenic Basidiomycota fungi.

Profiles of (a) selected GT, (b) AA and (c) CBM of the compared plant pathogens.

Abbreviations: GT glycosyltransferase, AA auxiliary activity, CBM carbohydrate binding module.
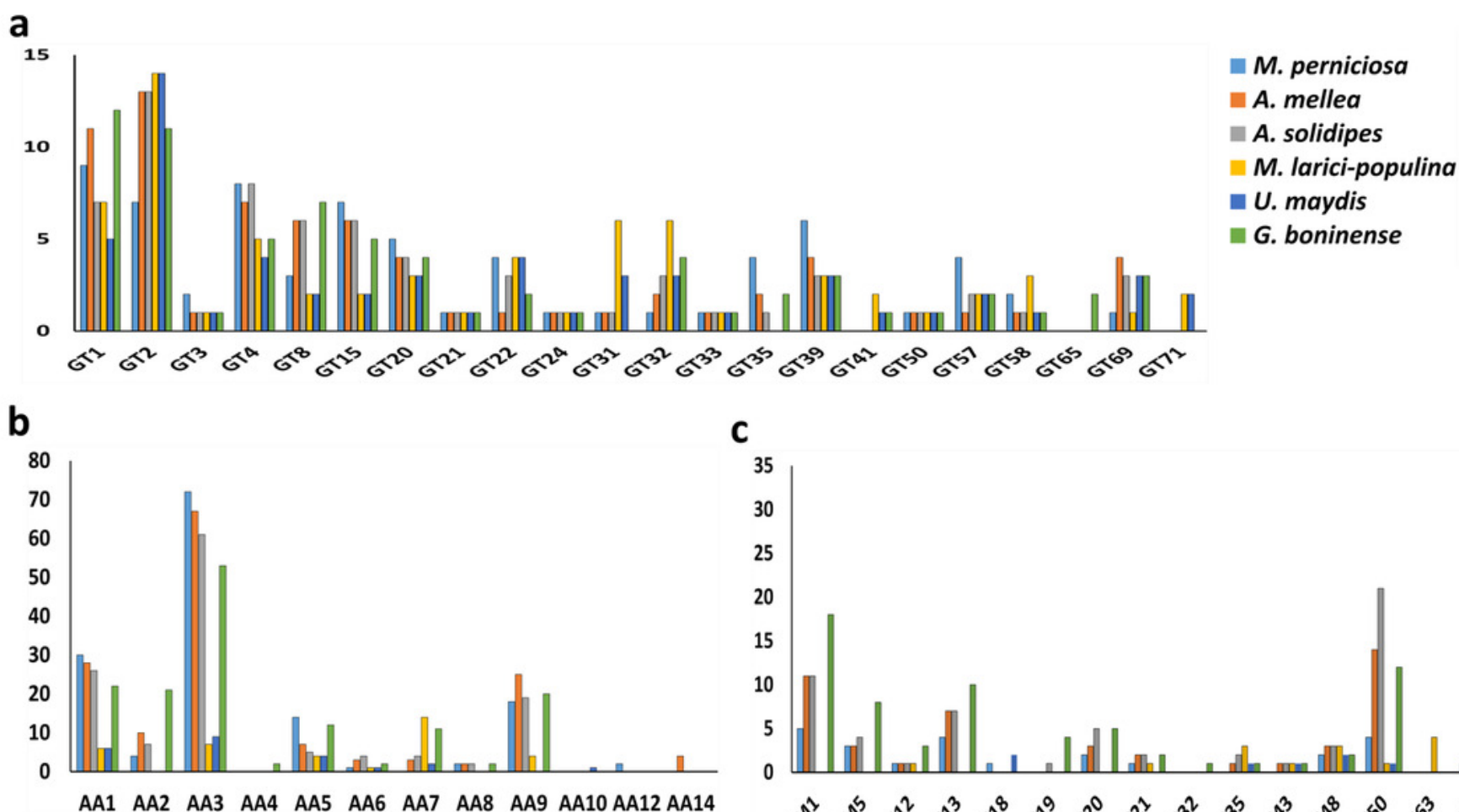

G. boninense

C

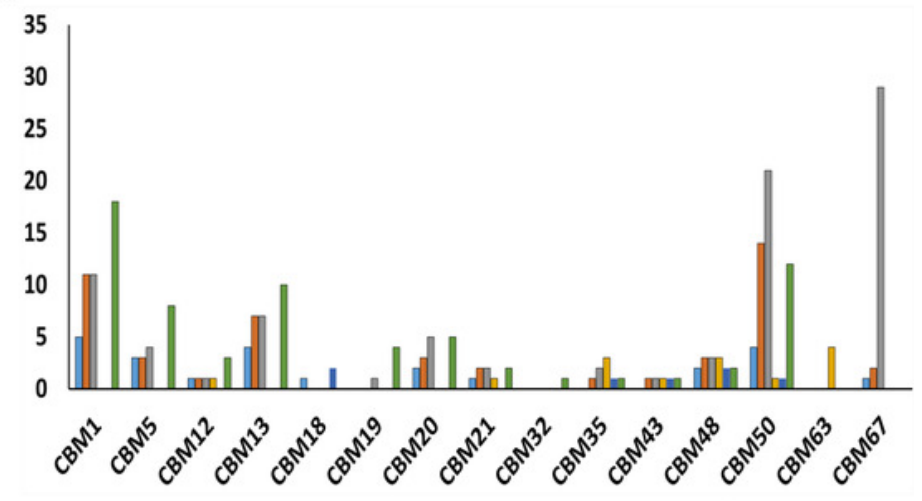


Figure 4

G. boninense NJ3 Augustus predicted amino acid sequences PhiBase 4.5 homologs classified based on gene ontologies

The gene ontology chart was generated using WEGO 2.0 (http://wego.genomics.org.cn/).

G. boninense NJ3 Augustus PHIbase 4.5 homologs

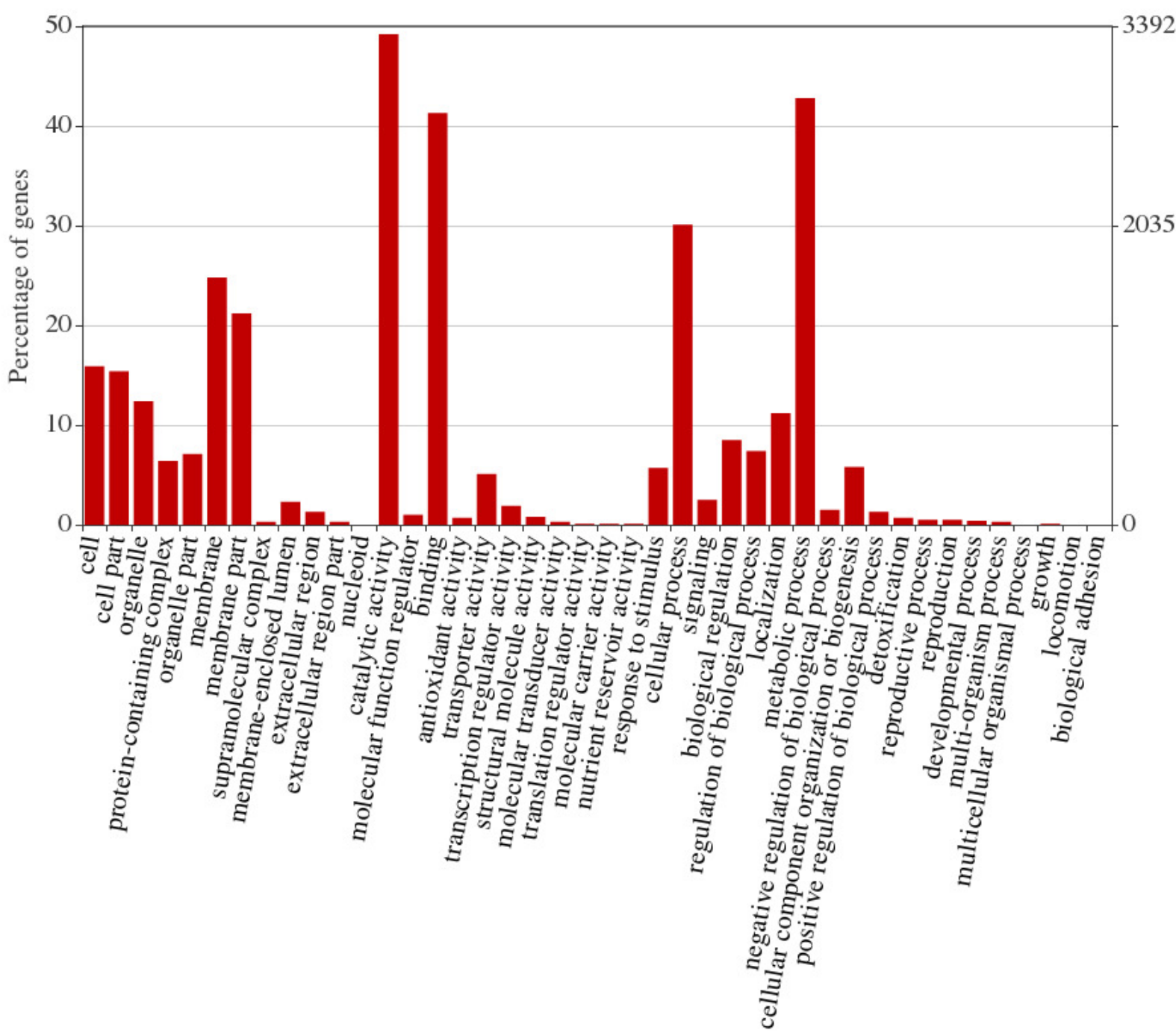




\section{Table $\mathbf{1}$ (on next page)}

List of candidate CWDE-related pathogenicity genes from PHI database analysis.

Information of homolog gene from reference organism is described in the table. 
1

2

\begin{tabular}{|c|c|c|c|c|c|}
\hline Gene & PHI ID & Protein ID & Organism & Function/Role & Reference \\
\hline PG1 & PHI:4879 & A0A0C4DHY2 & $\begin{array}{l}\text { Fusarium } \\
\text { oxysporum }\end{array}$ & $\begin{array}{l}\text { Catalysis of the random } \\
\text { hydrolysis of }(1,4) \text {-alpha-D- } \\
\text { galactosiduronic linkages in } \\
\text { pectate and other } \\
\text { galacturonans. }\end{array}$ & $\begin{array}{l}\text { (Bravo Ruiz, Di } \\
\text { Pietro \& } \\
\text { Roncero, 2016) }\end{array}$ \\
\hline $\begin{array}{l}\text { Endo-1,4- } \\
\text { beta- } \\
\text { xylanase } \\
\text { (GH10 } \\
\text { family) }\end{array}$ & PHI:2209 & G4N1Y8 & $\begin{array}{l}\text { Magnaporthe } \\
\text { oryzae }\end{array}$ & $\begin{array}{l}\text { Catalysis of the } \\
\text { endohydrolysis of }(1,4) \text { - } \\
\text { beta-D-xylosidic linkages in } \\
\text { xylans }\end{array}$ & $\begin{array}{l}\text { (Nguyen et al., } \\
\text { 2011) }\end{array}$ \\
\hline Eng1 & PHI:6265 & CONFK7 & $\begin{array}{l}\text { Histoplasma } \\
\text { capsulatum }\end{array}$ & $\begin{array}{l}\text { Catalysis of the hydrolysis } \\
\text { of any 0-glycosyl bond }\end{array}$ & $\begin{array}{l}\text { (Garfoot, } \\
\text { Andrew L. } \\
\text { Shen, Qian, } \\
\text { Wüthrich, } \\
\text { Marcel, Klein, } \\
\text { Bruce S., } \\
\text { Rappleye, } \\
\text { 2016) }\end{array}$ \\
\hline LCC2 & PHI:552 & Q96WM9 & Botrytis cinerea & $\begin{array}{l}\text { Lignin degradation and } \\
\text { detoxification of lignin- } \\
\text { derived products }\end{array}$ & $\begin{array}{l}\text { (Schouten et } \\
\text { al., 2002) }\end{array}$ \\
\hline
\end{tabular}

